\title{
The Relative Importance of Academic Activities: Autonomous Values from the Canadian Professoriate
}

Carlton Osakwe, Kalen Keavey, Faith-Michael Uzoka, Alan Fedoruk, \& Joseph Osuji Mount Royal University

\begin{abstract}
In this paper, we report findings on the contemporary idea of a university as defined by the relative importance of teaching, research, service, and collegiality in teaching-intensive universities. We also investigate Boyer's model of scholarship relative to the research-teaching-service nexus. Our findings show that while research is embraced as a key academic responsibility of professors, there is general agreement on the primacy of teaching. Equally, awareness of Boyer's model exposes faculty to diverse opportunities for scholarship and has the potential to open up faculty members to a new idea of the university.
\end{abstract}

\section{Résumé}

Dans cet article, nous présentons les résultats d'une recherche portant sur l'idée contemporaine de l'université, telle que définie par l'importance relative de l'enseignement, de la recherche, du service et de la collégialité dans des établissements d'enseignement intensif de niveau collégial ou universitaire. Notre recherche porte également sur le modèle boursier de Boyer, relatif au lien entre recherche, enseignement et service. Nos résultats démontrent que tandis qu'on voit la recherche comme une responsabilité académique des professeurs, il existe une entente générale quant à l'importance de l'enseignement. De même, le fait de connaître le modèle de Boyer, ouvre aux facultés d'enseignement la porte aux diverses opportunités d'obtention de bourses, et amène aussi à sensibiliser le personnel à une nouvelle pensée universitaire. 


\section{Introduction}

The concept of a university and the corresponding role of the academic professoriate are notions that have been debated and discussed over the centuries. The word "university" itself is derived from the Latin phrase universitas magistrorum et scholarium, which roughly translates as community of teachers and scholars, emphasizing that the original concept of the university was one of an institution designed to produce trained professionals, particularly in the fields of theology, law, and medicine (Hamlyn, 1996).

The modern concept of the North American university has its roots in the Humboldtian university model, conceived in Germany in 1810 by Wilhelm von Humboldt when he established the University of Berlin (Commager, 1963). The core tenet of this model is the union of "Lernfreiheit und Lehrfreiheit" (which loosely translates as "the freedom to teach and the freedom to conduct research"), and from this tenet emerged three principles that still persist, in varying degrees, at most universities today. ${ }^{1}$

1. A unity of research and teaching. The Humboldtian model changed the focus of universities from simply the dissemination of knowledge to the generation and dissemination of knowledge. As such, it is often considered the precursor of the modern research university (Geiger, 2004). It should be noted, however, that Humboldt actually envisioned research as an auxiliary academic function to teaching, and as necessarily a student-centered activity.

2. Academic freedom. This refers to the freedom of the individual teacher or researcher to choose what issues to study or teach, what methods to employ, and what avenues of dissemination to use, without interference or penalty (Global Colloquium of University Presidents, 2005). In 1940, the American Association of University Professors (AAUP) in its Statement of Principles provided what is still considered to be the standard definition of professorial academic freedom, characterizing it as: the freedom to conduct research and publish the results; the freedom in the classroom to teach one's subject; and the freedom to speak and write as other citizens do (AAUP, 2006).

3. Academic autonomy or self-governance. ${ }^{2}$ Related to but different from academic freedom, academic autonomy as argued by Humboldt refers to the ability of the institution to develop its own rules, regulations, and values without the interference of the state, and thus to be unencumbered by external political and economic pressures that could impede academic progress. This has sometimes resulted in the Humboldtian university model being characterized as the "republic of scholars" (Brubacher, 1967.)

While the first principle relates to the functions of the academic professoriate within universities, the second and third principles relate to immunizing those functions against religious, political, and economic influences. The interrelationship and implementation of these three principles have led to some of the well-known aspects of the academic structure of universities. Two examples of this stand out. First, the self-governance described by academic autonomy required active participation and personal interaction from the professoriate, consensus building for decision making, and overall good citizenship, leading to the notions of service and collegiality as academic responsibilities (Lapworth, 2004). ${ }^{3}$ Second, the protection of academic freedom led to the development of the system 
of tenure, first formally established in the 1915 Declaration of Principles by the American Association of University Professors, which stated that the "dignity" of the professorial office required the "security of tenure"4 (AAUP, 1915, p. 300).

The three Humboldtian principles have remained the central guiding elements in how most North American universities operate, but they have not gone unchallenged. Over the last 50 years, academic autonomy has been challenged by both government and industry, as universities have increasingly been "asked to justify their activities and account for their use of resources and their performance, not only to external financial bodies but also to other influential groups in society" (Sizer, 1992, p. 1306). However, despite this attack on financial autonomy, most indications are that the foundational principle of academic autonomy still applies, which means that most North American universities are governed in a manner that lets faculty members themselves be the ones who determine the dominant values of their academic activities. For example, the 2014 Canadian Association of University Teachers' (CAUT) Policy Statement on Governance states in part that "[a]cademic staff should be a majority in all bodies that make recommendations or decisions on academic matters in departments, faculties or schools or colleges" (CAUT, 2014, para. 6).

Academic freedom has been challenged mainly through censorship (often rationalized by invoking national interest) and declining tenure-track positions. A 2012 Statistics Canada report (Desjardins, 2012) shows the downward trend in the number of tenured and tenure-track faculty members at Canadian universities. The report states:

The overall proportion of tenured or tenure-track positions for doctorate holders working full-time in Canadian universities decreased by 10 percentage points between 1981 and 2007, decreasing from $79.8 \%$ in the 1980/1981 academic year to $70.3 \%$ in the $2006 / 2007$ academic year. The decline was even more pronounced for professors under the age of 35. In 1980/1981, one-third of professors under age 35 (35\%) held a full-time tenured or tenure-track position; 25 years later, this was true for only $12 \%$ of professors in that age category, a decrease of 23 percentage points. (p. 7)

Similarly, in the United States in 2013, The Huffington Post (Kingkade, 2013) reported:

In 1980, non-tenured part-time faculty comprised 32 percent of the total teaching force in higher education, according to a study by the National Center for Education Statistics. Today, non-tenured faculty now make up two-thirds of the higher education workforce, although the American Association of University Professors recommends no more than 15 percent of instruction within any institution be made up of non-tenure-track positions. (para. 7)

Perhaps the most fundamental challenge to the Humboldtian principles, however, has been the debate over the proper roles and responsibilities of the academic professoriate. Should academic functions be limited to teaching, research, and service, and how much relative emphasis should be placed on these functions in terms of workload and evaluation? This question is fundamental to the idea of a university because as an institution, the university is "a social structure that involves ... normative rules of interpretation and behavior" (Hodgson, 2006, p. 4). In other words, the university as an institution is defined by the generally accepted standards of academics' roles and responsibilities. 
From the end of the First World War to the 1980s, the perception that teaching was subordinate to research pervaded the general body of the academy, with prestige and financial reward conferred to institutions and individuals successfully involved in research (Mooney, 1992). A key turning point in this debate came, however, in 1990 from Ernest Boyer, when he called on universities to "move beyond the tired old 'teaching versus research debate" (p. 16). Boyer asked: "Is it possible to define the work of faculty in ways that reflect more realistically the full range of academic and civic mandates?” (p. 16). He argued that "a more comprehensive, more dynamic understanding of scholarship can be considered, one in which the rigid categories of teaching, research and service are broadened and more flexibly defined" (p. 16), and consequently he introduced a new model for academic activities that replaced teaching, research, and service with four types or "functions" of scholarship. "The work of the professoriate might be thought of as having four separate, yet overlapping, functions" (p. 16).

The Boyer model of scholarship, as it has become known, has achieved seemingly wide recognition at universities in North America, but the question still remains as to whether these new types of scholarship are activities "highly prized" by academics themselves (Davis \& Chandler, 1998). If the academic professoriate has indeed bought in to the model, then the Boyer functions of scholarship, purporting to cover the full range of academic activities in which the professoriate should be engaged, may very well have redefined the concept of a university.

In this paper, we seek to shed some light on the contemporary idea of a university, particularly in terms of the academic roles and responsibilities that are valued by the professoriate. We also seek to see whether and, if so, how Boyer's model has changed the narrative of this idea. We present results from a survey of faculty members at five universities in Canada, with a two-fold objective. First, we attempt to determine the relative importance of the various academic activities in the areas of teaching, scholarship, service, and collegiality, as perceived by faculty members themselves. Second, we explore whether Boyer's model has had an impact on the concept of a university, by examining whether academics have accepted the model into their culture and whether their institutions have adopted/implemented the model. In this regard, we also seek to identify what factors influence the institutional adoption of Boyer's model.

\section{Literature Review}

Since the establishment of the university as an institution of higher learning, the idea of what a university is has been wrapped in the debate over the appropriate role and responsibilities of the academic professoriate. The reason for this is clear. Institutions are defined as "systems of established and prevalent social rules that structure social interactions" (Hodgson, 2006, p. 2); so, the university as an institution is defined by the generally accepted standards for the activities of individuals within the university and the rules that enable or constrain these activities.

In the late nineteenth century, after the American civil war, visits by several hundred North American scholars to Germany resulted in the Humboldtian model of the university being transplanted to North American soil. This model proposed, for the first time, an emphasis on the union of teaching and research (Lernfreiheit und Lehrfreiheit) and enshrined the notions of academic freedom and academic autonomy within the university 
(Thelin, 2004). Prior to this, universities had been primarily teaching institutions and mostly focused on vocational studies. The Humboldtian model is thus often considered the template of the modern idea university. ${ }^{5}$ By the early twentieth century, with the advent of the faculty reward system of tenure and rank in North America, the research function of the professoriate had became the primary focus of academic work. This represented a significant adaptation of the Humboldtian model and established a new paradigm of the idea of a university. Under this paradigm, academic scholars were expected to conduct research-defined as "activity directed toward increasing the body of knowledge in their disciplines" (Feisel, 1995, para. 1)-publish their research studies in peer-reviewed journals, and incorporate the knowledge obtained from such research into their teaching and interactions with students. Two key components of this new North American paradigm were the notions of academic freedom and academic autonomy developed in the early twentieth century. Academic freedom meant the liberty to pursue and teach the truth regardless of where it led and was primarily ensured and protected by the invention of the tenure system (Horn, 1999). Academic autonomy meant self-governance within the university so that faculty controlled the academic agenda, and it led to the invention of the bicameral governance structure (Jones, Shanahan, \& Goyan, 2004). However, academic freedom and autonomy came with certain professional responsibilities, which included obligations to one another, to the greater good of the institution, and to society; consequently, collegiality and service became vital functions of the academic profession (Hamilton, 2002; Tierney, 1998). Over the next several decades, this North American paradigm came to be viewed as the "traditional" paradigm of the idea of a university.

As universities evolved into different types of higher education institutions (research universities, teaching universities, colleges, polytechnics, etc.), the debate re-emerged over where faculty should appropriately focus their efforts-and, in particular, over the relative importance of teaching versus research. While the actual number of "research universities" represented only a small percentage of higher education institutions, they were still considered the ideal model of the university, and as such, the traditional paradigm in which research was dominant still held sway (Mohrman, Ma, \& Baker, 2008).

After the Second World War, the Carnegie Foundation for the Advancement of Teaching began routinely surveying faculty members at all types of higher education institutions. It noticed the development of a need for a more inclusive view of a professor's work-one that would accommodate all the creative and inventive interests that can be found at universities and colleges-as well as a broader definition of university faculty, not just as professors but as scholars. An argument arose that scholarship should be reconceptualized beyond the archaic research-versus-teaching debate (O'Meara \& Rice, 2005), and that universities needed to broaden the definition of faculty work and scholarship beyond specific disciplinary boundaries.

In 1990, challenging the traditional paradigm, Ernest Boyer, the president of the Carnegie Foundation, asked: "[I]s it possible to define the work of faculty in ways that reflect more realistically the full range of academic and civic mandates?” (p. 16). According to Davis and Chandler (1998), Boyer's challenge to himself was "to define the work of faculty in ways that enrich rather than restrict the quality of campus life" (p. 1). Boyer answered his question and challenge by proposing a new model for the professoriate, which he based on an expanded and more inclusive concept of scholarship. Boyer insisted that 
the concept of scholarship for university faculties must include "the full spectrum of academic work and a redefinition of scholarship would honour the broad spectrum of work done by the professoriate" (p. 16). The so-called "Boyer model" proposed looking beyond the traditional focus of teaching, research, and service (with collegiality on the side) and identified four areas of scholarship that he felt were the "proper work of the faculty". These he labeled the scholarships of discovery, integration, application, and teaching.

The scholarship of discovery is most closely related to what traditionally has been understood as academic research. It refers to activities that add to the knowledge base of an academic discipline through "investigative efforts". According to Boyer (1990), this category comprises research undertaken due to "commitment to knowledge for its own sake, to freedom of inquiry, and to follow in a disciplined fashion, an investigation wherever it may lead" (p. 17). The scholarship of integration refers to activities that focus on "making connections across disciplines, placing specialties in larger contexts, illuminating data in a revealing way, often educating non-specialists" (p. 18), and thus create new or better insights into a more comprehensive body of knowledge. This type of scholarship is interdisciplinary, integrative, and interpretive. The scholarship of application refers to activities that use our knowledge to help professions and society as a whole in addressing the problems they face. According to Boyer, this type of scholarship "moves towards engagement-in service activities tied to one's special field of knowledge"'; it is not unidirectional, as new "intellectual understandings can arise out of the very act of application" (p. 22). The scholarship of teaching refers to activities related to the transfer of knowledge to students so that the continuity of knowledge is not broken. In doing so, this type of scholarship goes beyond just transmitting knowledge-it also transforms and extends it, as almost all academics credit their quest for knowledge and their career choice to some mentor who, through compelling teaching, created a spark that became a lifelong quest. Therefore, the scholarship of teaching honours the "transmitting, transferring and extending [of] knowledge" (p. 24). Boyer further recommended that universities maintain a supportive environment for all four forms of scholarship and that faculty be allowed to evolve through these four areas during their careers, rather than having to emphasize all or just one. His model of scholarship was designed to ensure that all manner of faculty work was recognized and valued at higher institutions, not just either research or teaching, as a one-dimensional approach encouraged.

Boyer's model for evaluating faculty scholarship has enjoyed critical acclaim and seemingly wide acceptance among many universities in their attempts to evaluate faculty work and scholarship. According to Glassick, Huber, and Maeroff (1997, p. 17), 62\% of universities in the United States reported that scholarship reconsidered played a part in discussions of faculty roles and rewards. Both the Canadian Association of Schools of Nursing (CASN, 2013) and the American Association of Colleges of Nursing (AACN, 1999) have endorsed the Boyer model to describe the full range of recognized scholarly work. However, despite its seemingly wide acceptance, actual implementation of the model has not been so widespread. Boyer developed his model while at the Carnegie Foundation for the Advancement of Teaching, and according to Lee S. Shulman, president of the foundation, "while colleges [and universities] have rushed to put Boyer's ideas into their mission statements, ... putting this philosophy in specific institutional tenure and promotion procedures is rare" (Jaschik, 2007). 
At a much more fundamental level, the question still remains as to whether or not Boyer's model of scholarship has ushered in a new paradigm of the idea of a university, a sort of neo-Humboldtian paradigm. Some authors have argued that the model does not necessarily constitute a new paradigm, since it is not a recognized comprehensive categorization of academic functions, and it ignores the social rules and social structures of universities as institutions (Davis \& Chandler, 1998). So, not only are many faculty members often not aware of this new definition of the professoriate, but those that are aware often change the rules by insisting on adding to the list of activities that constitute scholarship. ${ }^{6}$ This ever-expanding definition of scholarship occurs because Boyer's model does not address the issue of the underlying objectives behind scholarship activities and thus does not answer the following necessary question (Gurm, 2009): Who has the power to define scholarship and who determines what relative value should be placed on the various types of academic activities? This question is important since, as noted by Feisel (1995): "It is not clear that universities, either administration or faculty, do value the kind of scholar that Boyer defines" (para. 21).

The present study aims to address this question of relative importance by investigating the perceptions of faculty members themselves regarding the various activities in the areas of teaching, scholarship, service, and collegiality, and the nexus between them. For example, Clark (1994), in one of the earliest examinations of what is now called the research-teaching-study nexus, argues quite eloquently that the traditional tripartite paradigm of teaching, research, and service is fine as long as there is a strong nexus between them. A weak nexus, such as research being perceived as independently important from teaching, may have several dysfunctional outcomes, including (i) teaching time squeezing research into becoming a "spare-time activity", (ii) academics speaking to two different types of audience (research specialists and beginning students), resulting in poor communication with one or both, and (iii) research-led teaching, resulting in very narrow syllabi (Trowler \& Wareham, 2007).

The study also seeks to explore whether Boyer's model represents a new paradigm of the idea of a university, by exploring faculty and institutional broad awareness of the model and the factors that may influence its implementation at universities.

\section{Methodology}

\section{Data Collection Instrument}

The data-gathering instrument used in the research was a questionnaire consisting of three sections. The first section obtained anonymous demographic information about respondents. The second section obtained information on general perceptions regarding the relative importance of teaching, scholarship, service, and collegiality, as well as perceptions on the utilization of Boyer's model in universities. Note that the questionnaire asked for the respondents' personal perceptions and not what they thought were the institutional perceptions at their universities.

The questions were structured in a three- or five-point Likert-type scale, depending on the nature of the question. The third section was highly structured. It was designed to assist in obtaining academics' judgments on the pair-wise comparison of scholarship evaluation variables on a fuzzy linguistic analytic hierarchy process (AHP) scale (Kahra- 
man, Cebeci, \& Ruan, 2004; Saaty 1981). This paper reports the results of the first two sections of the questionnaire, as it seeks to investigate the current concept of a university in terms of the autonomously determined role of the academic professoriate, and to see whether and, if so, how the existing knowledge/use of Boyer's model in teaching-focused universities has had a major influence on this concept.

\section{Sampling Scheme}

The focus of this study was on universities that place a high emphasis on teaching. By examining the websites of universities in Canada, we found that most small and medium universities (in terms of student population) indicate a high focus on teaching relative to research. The study population was therefore chosen to be full-time faculty of teaching-focused, primarily undergraduate universities in Canada. The sampling method was judgment random sampling.

Of the small and medium, undergraduate, teaching-centered universities, five were chosen for inclusion in the study, based on the universities' size, type of programs, and geographic location. The universities selected were: Mount Royal, Mount Allison, St. Francis Xavier, Thompson Rivers, and Nipissing. Table 1 provides an overview of these universities.

Table 1.

Overview of Selected Universities ${ }^{7}$

\begin{tabular}{lcccc}
\hline University & $\begin{array}{c}\text { Year Estab. as } \\
\text { a University }\end{array}$ & $\begin{array}{c}\text { Full-Time } \\
\text { Enrolment }\end{array}$ & $\begin{array}{c}\text { \% Undergrad } \\
\text { Students }\end{array}$ & $\begin{array}{c}\text { Full-Time } \\
\text { Faculty }\end{array}$ \\
\hline Mount Allison University & 1886 & 2,450 & 99.2 & 165 \\
Mount Royal University & 2009 & 9,450 & 100.0 & 404 \\
Nipissing University & 1992 & 3,600 & 97.2 & 184 \\
St. Francis Xavier University & 1853 & 4,050 & 97.8 & 265 \\
Thompson Rivers University & 2005 & 6,610 & 97.3 & 425 \\
\hline
\end{tabular}

After obtaining ethics approval from each university's ethics board, we sent a total of 750 survey instruments to randomly selected full-time faculty at each of the five universities. The lists of faculty were compiled from publicly available website information, and 750 of these were chosen through random sampling. Of the 750 instruments sent out, 85 were returned, with 70 of the returned instruments properly filled out and considered useful for the analysis. ${ }^{8}$

\section{Processing}

The analysis presented in this paper involved the use of descriptive statistics to extract relevant information on the demographic composition of the respondents and issues such as their knowledge and utilization of Boyer's model. Kendall's tau_b and Spearman's rho 
correlation analyses were also applied to the responses relating to the emphasis on the individual evaluation parameters. These correlations were used to determine the relationships among variables such as evaluation parameter emphasis, tenure, knowledge of Boyer's model, and university application of Boyer's model. Finally, a number of variables were regressed against the institutional application of Boyer's model in order to identify some underlying factors that might influence the application of the model in universities. All analyses were carried out using the Statistical Package for the Social Sciences (SPSS) for Windows, Version 17.0.

\section{Results and Discussion}

Table 2 reports the demographic profile of the respondents. As was to be expected, the vast majority (over 80\%) possessed an earned doctorate degree, with $98.5 \%$ holding at least a master's degree. There were more male respondents than female ( $57 \%$ versus $43 \%$ ), but there was an almost uniform distribution of age across the three main age groups: $30-40,41-50$, and $51-60$ years. A small percentage (5.7\%) of faculty members were over 60 , but no one indicated being under 30 .

The largest proportion (45\%) of faculty members who responded were at the associate professor rank, with $32 \%$ at the assistant professor rank, and an additional $16 \%$ at the full professor rank. Only one respondent reported being at the rank of lecturer. As $70 \%$ of the respondents were reportedly non-tenured faculty, this suggests that tenure is not generally linked with promotion to associate professorship at most of the universities surveyed. Also, the fact that over $70 \%$ of the respondents were non-tenured could be indicative of the increase in non-tenure-track positions at universities across North America ${ }^{9}$ and highlights potentially reduced levels of academic freedom in the current university environment. Over a third of the respondents (37\%) reported having five to 10 years of experience as a faculty member, with over $50 \%$ reporting having fewer than 10 years of experience. Only $17 \%$ reported having more than 20 years of experience. Again, this could be a consequence of non-tenure-track faculty not having the longevity of employment possessed by tenured faculty.

In order to investigate the contemporary view of the idea of a university, one focus of this study was on the perceived relative importance of the academic activities of faculty members. Respondents were asked to report on their perceptions of teaching, research, service, and collegiality, and the results are presented in Table 3. Given the five-point Likert scale used here, the hypothesized or assumed mean response of 2.5 is that all academic activities are important. Table 3 then provides a sense of how relatively important these activities are perceived to be, showing that teaching is viewed as the most important. Over $90 \%$ of the respondents indicated that teaching was either important or extremely important, compared to $51.4 \%$ and $50 \%$ for research and service, respectively. As these are faculty members from primarily teaching institutions, these results are not too surprising. Note that as $81 \%$ of the respondents are graduates from doctoral programs, the perceived primacy of teaching has the potential to create a disconnect between what they were trained for (research) and what they were hired to do (teaching) unless the nexus between research and teaching is fully understood. 
Table 2.

Demographic Profile of Respondents

\begin{tabular}{|c|c|}
\hline Description & Percentage \\
\hline \multicolumn{2}{|l|}{ Academic Rank } \\
\hline Lecturer & 1.4 \\
\hline Assistant Professor & 32.9 \\
\hline Associate Professor & $45 \cdot 7$ \\
\hline Full Professor & $15 \cdot 7$ \\
\hline (missing) & $4 \cdot 3$ \\
\hline \multicolumn{2}{|c|}{ Highest Educational Level } \\
\hline Bachelor's Degree & 1.4 \\
\hline Master's Degree & 17.1 \\
\hline Doctorate Degree & 81.4 \\
\hline Other & 0.0 \\
\hline \multicolumn{2}{|c|}{ Age of Respondent (years) } \\
\hline$<30$ & 0.0 \\
\hline $30-40$ & 32.9 \\
\hline $41-50$ & 30.0 \\
\hline $51-60$ & 30.0 \\
\hline$>60$ & $5 \cdot 7$ \\
\hline (missing) & 1.4 \\
\hline \multicolumn{2}{|c|}{ Respondent's Gender } \\
\hline Male & 57.1 \\
\hline Female & 42.9 \\
\hline \multicolumn{2}{|c|}{ Years of Experience as Academic Faculty } \\
\hline$<5$ & 17.1 \\
\hline $5^{-10}$ & 37.1 \\
\hline $11-15$ & $15 \cdot 7$ \\
\hline $16-20$ & 12.9 \\
\hline$>20$ & 17.1 \\
\hline \multicolumn{2}{|l|}{ Tenure Status } \\
\hline Tenured & 27.1 \\
\hline Not tenured & 72.9 \\
\hline
\end{tabular}


Table 3.

Levels of Importance Attached to the Four Areas of Evaluation

\begin{tabular}{lcccc}
\hline Level of Importance & Teaching (\%) & Research (\%) & Service (\%) & Collegiality (\%) \\
\hline Extremely Important & 60.0 & 10.0 & 12.9 & 10.0 \\
Very Important & 30.0 & 41.4 & 37.1 & 22.9 \\
Important & 8.6 & 31.4 & 32.9 & 25.7 \\
Fairly Important & 1.4 & 12.9 & 14.3 & 27.1 \\
Not Important & 0.0 & 2.9 & 2.9 & 12.9 \\
No Response & 0.0 & 1.4 & 0.0 & 1.4 \\
\multicolumn{1}{c}{ Mean } & 4.49 & 3.39 & 3.43 & 2.86 \\
$\quad$ Standard Deviation & 0.711 & 1.018 & 0.981 & 1.234 \\
\hline
\end{tabular}

The results also imply that teaching is, loosely speaking, considered twice as important as research or service and that research and service are viewed as roughly equally important. ${ }^{10}$ While these results are only suggestive, they offer two considerations related to the current state of the idea of a university. First, as all four academic activities have a mean greater than 2.5 (that is, all are viewed as more than just "important"), the results suggest that universities may want to consider (or continue) evaluating faculty members on all four activities in order to provide them with the incentive to positively engage in all four. Second, the results suggest that universities consider allocating the recommended workload along the lines of relative importance, with the majority of faculty members' working hours being for teaching and the amounts allocated to research and service being about equal.

Table 4 presents the Pearson correlation coefficients for the academic activities above. There is a significant positive correlation between the importance placed on teaching and the importance placed on service and collegiality. This is consistent with the view that faculty members' participation in developing curricula and in mentoring and peer reviewing colleagues' teaching leads to interconnectedness between collegiality, service, and teaching. As stated in Allen, Abernethy, Ballenger, and Murdoch (2005), "A faculty member who cannot work willingly and effectively with colleagues also cannot contribute adequately to the activities needed to coordinate curricula, mentor new teachers, or sustain a productive community of scholars" (p. 1).

The importance of research is shown not to be significantly correlated with any of the other academic activities. This is striking because it indicates that, even at teaching-oriented universities, research is still currently perceived as being important for its own sake and not, in the Humboldtian tradition, as an auxiliary academic function that interacts with teaching, learning, and service. This independent research perspective may also be considered problematic because it implies a dissolution in the research-teaching-study nexus (Clark, 1994), with consequent dysfunctional outcomes such as the dual dissemination audience issue noted by Trowler and Wareham (2007). 
Table 4 .

Pearson Correlation Matrix

(The numbers in brackets are the $p$ values, and ${ }^{* *}$ indicates significant at the $1 \%$ level.)

\begin{tabular}{|c|c|c|c|c|}
\hline Pearson Correlation & Teaching & Research & Service & Collegiality \\
\hline Teaching & 1 & & & \\
\hline Research & $\begin{array}{c}.020 \\
(.870)\end{array}$ & 1 & & \\
\hline Service & $\begin{array}{c}.337^{* *} \\
(.004)\end{array}$ & $\begin{array}{r}-.180 \\
(.135)\end{array}$ & 1.0 & \\
\hline Collegiality & $\begin{array}{l}.403^{* * *} \\
(.001)\end{array}$ & $\begin{array}{r}-.013 \\
(.914)\end{array}$ & $\begin{array}{l}.326^{* *} \\
(.006)\end{array}$ & 1 \\
\hline
\end{tabular}

Boyer (1990) was also concerned about the research-teaching-study nexus but looked to expand on the Humboldtian principle by proposing a new contemporary model of the university, with academic functions being re-categorized as the "complementary" scholarships of discovery, integration, application, and teaching. In the 25 or so years since the Boyer model of scholarship was introduced into academia, it has become somewhat folklore that adoption of the model is widespread at academic institutions and has changed the narrative of the idea of a university. Hence, another focus of our study was to examine how aware the academic professoriate really were about Boyer's model and what their perceptions were of the institutional awareness and implementation of the model at their universities. Table 5 shows the survey results for some of the questions asked about Boyer's model.

One initial and somewhat surprising result is that a substantial majority of the faculty respondents (60\%) reported that they were unfamiliar with Boyer's model. A check to see whether awareness of the model was in some way related to the size of the institution resulted in a correlation of 0.274 , which does not suggest a significant relationship. Irrespective of whether or not they were aware of Boyer's model, faculty were asked whether they perceived one form of scholarship to be more highly valued at their institution than others, and exactly 50\% responded that they did. Thus, even for those faculty members unaware of Boyer's typology of scholarship, there was still some recognition that there are varied types of academic pursuit, but that, presumably, traditional "pure" research-otherwise known as the scholarship of discovery (Boyer, 1990, p. 16-17)-was valued most highly by the universities. Of those respondents who were aware of Boyer's model, over $70 \%$ reported that their knowledge of its details was either good, very good, or excellent, with only $3.6 \%$ replying that their knowledge was poor (this proved to be uncorrelated to the size of the institution). Again, over $70 \%$ also responded that their university had some level of implementation of Boyer's model in their faculty evaluation criteria, with $50 \%$ of the universities formally embedding the model in their policy and procedure statements.

With such a large percentage of universities formally or informally applying Boyer's model, it would be expected that routine mechanisms would be established to provide faculty with awareness of the model-and indeed, over $50 \%$ of faculty reported that their 
universities do provide such mechanisms, but on an as-needed basis. Surprisingly, not a single university provided such an awareness mechanism at the orientation programs for new faculty or at annual forums. This can be viewed as troubling, since it implies that faculty might be being evaluated on a model of which they have not been made aware.

Table 5 .

Section of Questionnaire on Boyer's Model

Have you heard of Boyer's model of scholarship?

Yes

No

For Respondents who have heard of Boyer's model:

How would you rate your knowledge of the details of the Boyer's model of scholarship?

Excellent

Very Good

Good

Fair

Poor

If your University applies the Boyer's model of scholarship, is there an established mechanism for providing awareness to faculty of the details of the Boyer's model?

Only once during the initial orientation programme for new faculty

Annually at a given awareness forum

There is no such awareness mechanism in my University

Occasionally, when the need arises

No Response

Has your University modified the model (added to it or reduced it)?

No, they are using the four categories as described by Boyer

Yes, they have added categories

Yes, they have reduced/consolidated the number of scholarship categories

At your institution, are Faculty encouraged to be involved in all four of Boyer's scholarship types, namely: Scholarship of Discovery, Scholarship of Integration, Scholarship of Application, and Scholarship of Teaching and Learning?

Yes

No

At your institution are Faculty required to declare which area of scholarship they will focus on and subsequently be assessed on?

Yes

No

Does your Institution rank one category of scholarly activity higher than others?

No, all are equally weighted

Yes, some forms of scholarship are considered more important than others. 
Table 6 presents the Pearson correlation coefficients for the academic activities in Table 2 with the variables on Boyer's model from Table 5. For robustness, the non-parametric Spearman's and Kendall's rank correlations were also computed, and they gave the same results with respect to the signs and significance of correlations. From the table we see that while the perceived importance of research does not appear significantly correlated with other academic activities (from Table 4), here it is significantly negatively correlated with knowledge about Boyer's model. On the one hand, this might indicate that greater awareness of Boyer's model opens faculty members up to the importance of other aspects of scholarship, not just the scholarship of discovery (traditional research). However, on the other hand, it might indicate that faculty members who perceive traditional research as most important may have the least interest in Boyer's model, while faculty members who do not prioritize traditional research are more likely to be drawn to Boyer's model. ${ }^{11}$ We believe the former to be the more reasonable interpretation, as the correlation relates to the awareness of Boyer's model rather than its importance.

Table 6.

Pearson Correlation Matrix

(The numbers in brackets are the $p$ values, and ${ }^{*}$ and ${ }^{* *}$ indicate significance at the $5 \%$ and $1 \%$ levels, respectively.)

\begin{tabular}{lccccccc}
\hline $\begin{array}{l}\text { Pearson } \\
\text { Correlation }\end{array}$ & Teaching & Research & Service & Collegiality & Tenure & $\begin{array}{c}\text { Boyer } \\
\text { Knowledge }\end{array}$ Mechanism \\
\hline Tenure & .170 & -.162 & .225 & .158 & & & \\
& $(.159)$ & $(.180)$ & $(.061)$ & $(.193)$ & 1 & & \\
Boyer & -.089 & $-.237^{*}$ & .060 & -.085 & $.254^{*}$ & 1 & \\
Knowledge & $(.461)$ & $(.048)$ & $(.621)$ & $(.484)$ & $(.034)$ & & \\
Awareness & -.089 & -.150 & .128 & -.039 & $.251^{*}$ & $.773^{* *}$ & 1 \\
Mechanism & $(.463)$ & $(.215)$ & $(.292)$ & $(.746)$ & $(.036)$ & $(.000)$ & \\
\hline
\end{tabular}

It can also be seen that knowledge about Boyer's model is positively correlated with being tenured. This could again be indicative of junior faculty not being adequately made aware of relevant evaluation criteria.

\section{Regression Analysis}

Since the mid-20 ${ }^{\text {th }}$ century, universities in Canada have largely operated under a bicameral governance structure, with faculty senate (the terminology for the central academic decision-making body may differ for different institutions) being responsible for the "academic affairs" of the institution (Jones, Shanahan, \& Goyan, 2004). This, combined with the move towards faculty unionization that began in the 1970s, has resulted in the professoriate at most universities being the deciding body as to whether a particular model of academic activities or scholarship will be adopted by the institution to either assign workload or evaluate faculty performance for tenure and promotion. Therefore, to 
analyze whether Boyer's model of scholarship may be successfully adopted by a university, it is important to understand how this process may be influenced by faculty members' perceptions of their academic responsibilities.

The dependent variable in this analysis is the level of institutional adoption of Boyer's model (LOA). This was measured by a three-point Likert Scale in which " 3 " indicated a high level of adoption, with the university formally embedding the model in policies and procedures, " 2 " indicated a medium level of adoption, with the university informally applying the model through attitudes and practices, and " 1 " indicated no level of adoption, with the university not applying the model at all to evaluate faculty.

The least squares regression model used was:

$$
\mathrm{LOA}=\beta_{0}+\beta_{1} \mathrm{SIZE}+\beta_{2} \mathrm{TEACH}+\beta_{3} \mathrm{RSCH}+\beta_{4} \mathrm{SRVC}+\beta_{5} \mathrm{CLLG}+\beta_{6} \mathrm{DGREE}+\beta_{7} \mathrm{GEND}
$$

where:

LOA: level of institutional adoption of Boyer's model

SIZE: institution's size by number of students

TEACH: faculty members' perception of the importance of teaching

RSCH: faculty members' perception of the importance of research

SRVC: faculty members' perception of the importance of service

CLLG: faculty members' perception of the importance of collegiality

DGREE: faculty members' academic credential

GEND: faculty members' gender

As the focus of the study is on the perceived relative importance of academic activities, we included the variables DGREE and GEND in the above regression model to control for adoption being influenced by education or gender predominance. To check for multicollinearity, both a Tolerance test and a Variance Influence Factor (VIF) were utilized (Kleinbaum, Kupper, \& Muller, 1988). In all cases, the Tolerance was $>0.05$ and the VIF was $<2$, indicating no multicollinearity amongst the independent variables in this study.

Table 7 presents the regression results. The coefficients for the control variables for academic credential (DGREE) and gender (GEND) are statistically insignificant. The overall regression model, however, is significant at the $1 \%$ level, with the independent variables explaining $23.6 \%$ of the variance in adoption levels. The coefficient on institutional size (SIZE) is positive and statistically significant at the $5 \%$ level, indicating that larger teaching-focused universities are more likely to adopt Boyer's model. To understand this result, note from table 1 that the smaller teaching-focused universities are, in general, the older universities. This indicates that as smaller teaching-focused universities are more likely to be older and established in their traditions, as well as more likely to be influenced by the traditional Humboldtian model, Boyer's model of scholarship will be less likely to be adopted. The coefficient on the importance of research (RSCH) is also significant at the $5 \%$ level but is negative, indicating that as faculty members view traditional research to be less important, the institution at which they work is more likely to adopt Boyer's model. Conversely, it indicates that the more that faculty at an institution view traditional research to be of greater importance, the less likely it is that Boyer's model-which offers an expanded definition of scholarship and promotes equal recognition of all forms-will 
be adopted. This is an interesting finding and may underscore an attitude among faculty members that any type of activity other than traditional research is second-rate and pursuing it may limit one's academic career (for example, in terms of mobility across institutions). In fact, Schweitzer (2000) reported that this attitude nearly undermined the attempt to formally adopt Boyer's model at the University of Louisville.

Lastly, the coefficient on the importance of collegiality (CLLG) is statistically significant at the $5 \%$ level and is positive, indicating that as faculty view collegiality to be more important, the institution at which they work is more likely to adopt Boyer's model. This result is in agreement with previous studies on faculty collegiality. For example, Massey, Wilger, and Colbeck (1994) found that the traditional evaluation and reward system, which places primary importance on traditional research, can cause isolation and create competitive rather than cooperative behaviour in faculty, which inhibits collegiality. The more faculty members value collegiality, the more likely they will therefore be to adopt a system of evaluation and reward that is more inclusive of a wider variety of academic activities.

The coefficient on the importance of teaching, while marginally insignificant, is negative, indicating that as faculty view teaching to be more important, the institution at which they work is less likely to adopt Boyer's model. Given that Boyer's model advocates for the scholarship of teaching and learning, and that it be recognized and rewarded on par with traditional research (the scholarship of discovery), this result is a bit surprising.

Table 7.

Regression of the Level of Institutional Adoption of Boyer's Model (LOA) Against Perception Variables

\begin{tabular}{cccccc}
\hline Dependent Variable & \multicolumn{5}{c}{ LOA } \\
\cline { 2 - 6 } Regression Model: & $\begin{array}{c}\text { Coeffi- } \\
\text { cients }\end{array}$ & $t$ & $p$ value & Tolerance & VIF \\
\hline (Constant) & & -0.549 & 0.585 & & \\
SIZE & $.311^{* *}$ & 2.436 & 0.018 & 0.755 & 1.324 \\
TEACH & -.209 & -1.643 & 0.105 & 0.759 & 1.318 \\
RSCH & $-.294^{* *}$ & -2.541 & 0.014 & 0.921 & 1.085 \\
SRVC & .078 & 0.596 & 0.554 & 0.711 & 1.406 \\
CLLG & $.301^{* *}$ & 2.363 & 0.021 & 0.761 & 1.314 \\
DGREE & .067 & 0.565 & 0.574 & 0.865 & 1.157 \\
GEND & .177 & 1.564 & 0.123 & 0.961 & 1.040 \\
\hline
\end{tabular}

* Significant at 10\% ** Significant at 5\% $\quad{ }^{* * *}$ Significant at $1 \%$

Model Summary

\begin{tabular}{|c|c|c|c|c|c|c|c|}
\hline $\mathrm{R}$ & R Square & $\begin{array}{c}\text { Adj. R } \\
\text { Square }\end{array}$ & $\begin{array}{c}\text { Std. Err. } \\
\text { of } \\
\text { Estimate }\end{array}$ & F Change & df1 & df2 & $\begin{array}{c}\text { Sig. F } \\
\text { Change }\end{array}$ \\
\hline .485 & .236 & .149 & .957 & 2.731 & 7 & 62 & 0.015 \\
\hline
\end{tabular}




\section{Conclusion}

The idea of a university is framed by the roles and responsibilities of academics, the relationship or nexus between the activities defined by these roles and responsibilities, and the relative importance of these academic activities. Recently, the categorization of academic functions and the corresponding idea of a university have been impacted by the advent of the Boyer model, which provided the impetus for us to re-examine the nexus between teaching, research, and service.

The principles of the professoriate's academic freedom and academic autonomy imply that faculty members themselves are the ones who determine the dominant values of academic activities in universities and colleges. Therefore, the debate over what academics' proper roles and responsibilities are cannot properly proceed without an understanding of the relative importance that academics themselves place on the functions of teaching, scholarship, service, and collegiality. In this study, we surveyed faculty to determine just that, and our study thus represents a starting point in the discussion of what the current dominant values of academics are and what the contemporary idea of a university is.

Our results suggest that while professors at teaching-intensive universities do embrace research as a key academic responsibility, there is general agreement on the primacy of teaching over research and service. We also find, however, that while there are strong correlations between teaching and service/collegiality, the relative importance placed on research is independent of the importance placed on teaching, service, or collegiality. This indicates a weak nexus between research and the other academic functions, and a continued departure from the Humboldtian concept of research as an academic function auxiliary to teaching, learning, and service. The importance of research is, however, negatively related to knowledge of Boyer's model of scholarship, which may suggest that as academics more widely adopt Boyer's model, they place less importance on the "traditional paradigm" of independent research as an academic activity.

Although there is much mention in the literature of the widespread adoption of Boyer's model of scholarship, the results of our study indicate that awareness of Boyer's model is not as prevalent as it may seem, and that this awareness is more likely to be at larger institutions than smaller ones. The majority of professors in the surveyed universities (60\%) were unfamiliar with Boyer's model of scholarship. It is also interesting to note that despite the tendency to apply Boyer's model in faculty scholarship evaluations (formally or informally), we find that universities do not seem to have mechanisms for creating awareness among faculty of the existence and utilization of such a model. However, despite this lack of awareness, faculty seem to agree on the existence of various forms of scholarship, and the need to consider some forms of scholarship as more important than others. Finally, we find that universities are more likely to adopt Boyer's model if faculty members perceive collegiality to be important, and so, the contemporary idea of a university may be based on how much value is placed on collegiality.

\section{Notes}

1. Kweik (2006) has argued that the Humboldt model has another principle, that of the central importance of the faculties of arts and science.

2. These three paradigms that emerged from the Humboldtian model have also been 
stressed in the Magna Charta Universitatum, which is a declaration on fundamental university principles, drafted in Bologna in 1988, that has now been signed by some 750 universities worldwide.

3. For example, Langfeldt and Kyvik (2011) report that faculty members spend 20-25 full days per year devoted to evaluating colleagues' work.

4. Metzger (1973) has pointed out that the notion of tenure actually dates back to the middle ages. However, the AAUP's 1915 declaration was the first formal expression of this principle, which was then further codified in its 1940 Statement of Principles; these outlined that tenure should guarantee that the professoriate cannot be dismissed except for causes such as gross professional incompetence.

5. The main competing approach was the Newman model, which proposed that universities should primarily be teaching organizations that emphasized undergraduate education. See The Idea of the University: A Reexamination, by Jaroslav Pelikan (1992).

6. For example Kwantlen Polytechnic University has added the category "scholarship of creative activity" (Gurm, 2009, p. 5).

7. The student enrolment and undergraduate percentage numbers in this table were obtained from the AUCC 2013 "Facts and Stats" (http://www.aucc.ca/canadian-universities/facts-and-stats/enrolment-by-university/). The faculty numbers were obtained from the universities' websites.

8. The third section of the questionnaire was designed to collect data for use in an accompanying AHP study, which is reported in a companion paper (Uzoka, Fedoruk, Osakwe, Osuji, \& Gibb, 2013). The complexity of the third section of the questionnaire may have affected the response rate.

9. The $70 \%$ number reported here is lower than the $78 \%$ reported in the 2009 data from the National Center for Education Statistics (Knapp, Kelly-Reid, \& Ginder, 2010).

10. ANOVA testing (not reported here) indicates that the levels of importance attached to teaching, scholarship, service, and collegiality were not significantly different across various faculty groupings.

11. Our thanks to an anonymous referee who pointed out this alternative interpretation.

\section{References}

Allen, M., Abernethy, R., Ballenger, N., \& Murdock, M. (2005). Best practices for considering collegiality and service as components of academic performance. University of Wyoming Pythian Papers on Academic Careers. Retrieved from http://www.uwyo. edu/acadaffairs/_files/docs/collegiality_service.pdf

American Association of Colleges of Nursing. (1999). Defining scholarship for the discipline of nursing. Retrieved from http://www.aacn.nche.edu/publications/position/ defining-scholarship

American Association of University Professors. (1915). Appendix I: 1915 declaration of principles on academic freedom and academic tenure. Available from http://www. aaup.org/report/1915-declaration-principles-academic-freedom-and-academic-tenure

American Association of University Professors. (2006). 1940 statement of principles on academic freedom and tenure with 1970 interpretive comments. Retrieved from http://www.aaup.org/report/1940-statement-principles-academic-freedom-and-tenure 
Boyer, E. L. (1990). Scholarship reconsidered: Priorities of the professoriate. Princeton, NJ: Carnegie Foundation for the Advancement of Teaching.

Brubacher, J. S. (1967). The autonomy of the university: How independent is the republic of scholars? The Journal of Higher Education, 38(5), 237-249.

Canadian Association of Schools of Nursing. (2013). Position statement on scholarship in nursing. Retrieved from http://casn.ca/wp-content/uploads/2014/10ScholarshipinN ursingNov2013ENFINALmm.pdf

Canadian Association of University Teachers. (2014). CAUT policy statement on Governance. Retrieved from http://www.caut.ca/about-us/caut-policy/lists/caut-policystatements/caut-policy-statement-on-governance

Clark, B. (1994). The research-teaching-study nexus in modern systems of higher education. Higher Education Policy, 7(1), 11-17.

Commager,H.S.(1963). The university and freedom: "Lehrfreiheit" and "Lehrnfreiheit". The Journal of Higher Education, 34(7), 361-370.

Davis, W. E., \& Chandler, T. J. L. (1998). Beyond Boyer's scholarship reconsidered: Fundamental change in the university and the socioeconomic systems. The Journal of Higher Education, 69(1), 23-64.

Desjardins, L. (2012). Profile and labour market outcomes of doctoral graduates from Ontario universities. Statistics Canada: Culture, Tourism and the Centre for Education Statistics. Retrieved from http://www.statcan.gc.ca/pub/81-595-m/81-595-m2012098eng.htm

Feisel, L. D. (1995). Scholarship reconsidered - A reality check. Message posted to http://www.inform.umd.edu. Retrieved from http://confchem.ccce.divched.org/sites/ confchem.ccce.divched.org/files/1995FallConfChemP2.pdf

Flavelle, J. \& Smith, G. (1906). Report of the royal commission on the University of Toronto. Toronto, ON: LK Cameron.

Geiger, R. L. (2004). To advance knowledge: The growth of American research universities, 1900-1940. New Brunswick, NJ: Transaction.

Glassick, C. E., Huber, M. T., \& Maeroff, G. I. (1997). Scholarship assessed: Evaluation of the professoriate. Special report. San Francisco, CA: Jossey-Bass.

Global Colloquium of University Presidents. (2005). Academic freedom and international migration. New York, NY: Columbia University.

Gurm, B. K. (2009). Is all scholarship equally valued? Fusion of horizons on the definition and status of scholarship. International Journal for the Scholarship of Teaching and Learning, 3(2), 1-10.

Hamilton, N. (2002). Academic ethics: Problems and materials on professional conduct and shared governance. Westport, CT: Praeger.

Hamlyn, D. W. (1996). The concept of a university. Philosophy, 71(276), 205-218.

Hodgson, G. M. (2006). What are institutions? Journal of Economic Issues, 4O(1), 1-25.

Horn, M. (1999). Academic freedom in Canada: A history. Toronto, ON: University of Toronto Press. 
Jaschik, S. (2007). Scholarship reconsidered as a tenure policy. Message posted to http://www.insidehighered.com/news/2007/10/02/wcu

Jones, G. A., Shanahan, T., \& Goyan, P. (2004). The academic senate and university governance in Canada. The Canadian Journal of Higher Education, 34(2), 35-68.

Kahraman, C., Cebeci, U., \& Ruan, D. (2004). Multi-attribute comparison of catering service companies using fuzzy AHP: The case of Turkey. International Journal of Production Economics, 87(2), 171-184.

Kingkade, T. (2013, January 23). Tenure decline: Inside Higher Ed survey finds provosts relying on non-tenured faculty. The Huffington Post. Retrieved from http:// www.huffingtonpost.com/2013/01/23/tenure-decline_n_2537418.html

Kleinbaum, D. G., Kupper, L. L., \& Muller, K. E. (1988). Applied regression analysis and other multivariate methods. Belmont, CA: Duxbury Press.

Knapp, L. G., Kelly-Reid, J. E. \& Ginder, S. A. (2010). Employees in postsecondary institutions, fall 2009, and salaries of full-time instructional staff, 2009-10. U.S. Department of Education, National Center for Education Statistics. Retrieved from http://nces.ed.gov/pubs2011/2011150.pdf

Kweik, M. (2006). The classical German idea of the university, or on the nationalization of the modern institution. Center for Public Policy (CPP) Research Papers Series, 1, 1-60.

Langfeldt, L., \& Kyvik, S. (2011). Researchers as evaluators: Tasks, tensions and politics. Higher Education, 62, 199-212.

Lapworth, S. (2004). Arresting decline in shared governance: Towards a flexible model for academic participation. Higher Education Quarterly, 58(4), 299-314.

Massy, W. F., Wilger, A. K., \& Colbeck, C. (1994). Departmental cultures and teaching quality: Overcoming a "hollowed" collegiality. Change: The Magazine of Higher Learning, 26(4), 11-20.

Metzger, W. (1973). Academic tenure in America: A historical essay. In Faculty tenure: A report and recommendations by the Commission on Academic Tenure in Higher Education. San Francisco, CA: Jossey-Bass.

Mohrman, K., Ma, W., \& Baker, D. (2008). The research university in transition: The emerging global model. Higher Education Policy, 21, 5-27.

Mooney, C. (1992, March 25). Syracuse seeks a balance between teaching and research. The Chronicle of Higher Education. Available from http://chronicle.com/article/ Syracuse-Seeks-a-Balance/79554/

O’Meara, K., \& Rice, E. R. (2005). Faculty priorities reconsidered: Rewarding multiple forms of scholarship. San Francisco, CA: Jossey-Bass.

Pelikan, J. (1992). The idea of the university: A reexamination. New Haven, CT: Yale University Press.

Saaty, T. L. (1981). Priorities in systems with feedback. International Journal of Systems, Measurements and Decisions, 1, 24-38.

Schweitzer, L. (2000). Case study: Adoption and failure of the "Boyer model" at the University of Louisville. Academic Medicine, 75(9), 925-929. 
Sizer, J. (1992). Accountability. In B. Clark \& G. Neave (Eds.), Encyclopedia of Higher Education, Vol. II: Analytical Perspectives(pp.1305-1313. Oxford, UK: Pergamon Press.

Thelin, J. (2004). A history of American higher education. Baltimore, MD: The Johns Hopkins University Press.

Tierney, W. G. (1998). Tenure is dead: Long live tenure. In W. G. Tierney (Ed.), The responsive university: Restructuring for high performance (pp. 38-61). Baltimore, MD: The John Hopkins University Press.

Trowler, P., \& Wareham, T. (2007). Tribes, territories, research and teaching: Enhancing the 'teaching-research nexus'. Literature review. Report to the Higher Education Academy. Retrieved from http://www.lancs.ac.uk/fass/projects/nexus/ documents/Deliverable_1__literature_revi ew_13.9.7.doc

Uzoka, F., Fedoruk, A., Osakwe, C., Osuji, J., \& Gibb, K. (2013). A multi-criteria framework for assessing scholarship based on Boyer's scholarship model. Information Knowledge Systems Management, 12(1), 25-51. doi:10.3233/IKS-130215

\section{Contact Information}

Faith-Michael Uzoka

Department of Computer Science and Information Systems

Mount Royal University

fuzoka@mtroyal.ca

Carlton Osakwe holds a BSc in chemical engineering from the University of Ife, an MBA in finance from Howard University, and a PhD in finance from McGill University. He has taught at McGill University, the University of Toronto, and the University of Calgary and is currently an associate professor of finance at Mount Royal University, Calgary.

Kalen Keavey, BSc, MLIS, is an associate professor in the Mount Royal University Library. She is also the Coordinator of Library Information Systems and the Computer Science Librarian. Her research interests include Boyer's model implementations, gender issues in IT education, transliteracy, and the digital divide.

Faith-Michael Uzoka is a full professor in the Department of Computer Science and Information Systems at Mount Royal University, Calgary. He is a cross-disciplinary researcher, applying information systems and computing principles in multiple aspects of human endeavour, especially in medicine, human resources evaluation, and education. He has collaborated with numerous researchers to apply soft computing solutions to real-life problems and has served on the editorial boards of several journals and conferences.

Dr. Joseph Osuji is an associate professor at the Mount Royal University School of Nursing. His current teaching assignments are medical/surgical clinical experiences, pharmacology, pathophysiology, and chronic disease management. He is interested in research questions that deal with the social determinants of health, informatics, teaching and learning evaluations, and homelessness and has published in these areas. Joseph volun- 
teers for several community associations, including the Calgary Homeless Foundation and the Calgary Centre of Hope, and is a member of the Developmental Disabilities Resource Centre, Calgary. He is also a member of several professional associations.

Alan Fedoruk is an associate professor at Mount Royal University. He completed his BSc at the University of British Columbia, his MSc at the University of Saskatchewan, and his $\mathrm{PhD}$ at the University of Calgary. His research interests are artificial intelligence, multicriteria optimization, and data mining, and his teaching interests are in databases, data mining, as well as computers and society. Alan also has 15 years' experience working in the IT industry, which is a great asset to his research and teaching portfolio. When not at his computer, you can find Alan climbing and skiing in the Canadian Rockies. 